\title{
Portfolio Diversification With NAFTA Equities
}

Carl M. Hubbard, Trinity University

E. Dante Suarez, (E-mail: esuarez@trinity.edu), Trinity University

\begin{abstract}
The results of our analysis suggests that diversified investment in the Mexican stock market has provided significant diversification and returns enhancement benefits to U. S. investors and that Canadian stocks offer only occasional return/risk improvement over a U.S. equities portfolio. When correlations among the three markets are considered, we see diversification opportunities in the longer periods of returns but also increasing convergence of the Mexican and Canadian markets with the U.S. stock market in recent years. The implications of our findings are that, if 17 years of returns data are representative of future expectations, there are clear return/risk enhancing advantages to including Mexican stocks in U.S. portfolio.
\end{abstract}

\section{INTRODUCTION}

1

$\mathrm{n}$ this paper we analyze the extent to which the risk premium relative to risk of an equities portfolio diversified across U.S. stocks may be enhanced by the inclusion of Canadian and Mexican equities. The main results of the analysis indicate that in the 1988 to 2004 monthly returns data an optimized portfolio of equities included about one-third Mexican and two-thirds U.S. stocks. By combining a diversified portfolio of Mexican stocks with the S\&P 500, the total return of the resulting portfolios increased, risk also increased, but return relative to risk increased resulting in a substantial optimal portfolio allocation of equities from Mexico. This finding may be a result of decades of liberalizations of the Mexican economy that have promoted economic growth and higher stock returns. The North American Free Trade Agreement (NAFTA) also has promoted free trade, economic integration, and economic growth of the three partners - U.S., Mexico, and Canada. We also present evidence that suggests that Canadian stocks have offered less significant return/risk improvement over a domestic U.S. portfolio. Our conclusions regarding the diversification advantages of the inclusion of Mexican stock in U.S. portfolios are weakened somewhat by a trend toward higher correlation with the U.S. stock market; however, the return advantages of Mexican stocks have persisted through the sample period with exception of the period of Peso devaluation in the mid-1990's.

As discussed below, evidence of the return/risk advantages of international diversification in financial literature is pervasive. Many different techniques, country samples and time periods have yielded results showing the return/risk advantages resulting from international diversification. It is now conventional wisdom that foreign assets are attractive as a source of portfolio diversification, as they are subject to sources of variability that are not present in the U.S. Many American investors, however, remain reluctant to invest abroad, especially in an emerging market such as Mexico. Our research is generally supportive of the position of Errunza and Losq (1987), who contend that investors should not categorically avoid the emerging financial markets in developing economies. Mexico as an example of an emerging market has offered clearly superior portfolio return and diversification opportunities for U.S. investors. Our findings also correspond with those of Bekaert, et al. (1999) who caution readers that the perceived diversification advantages of emerging markets stocks are time period specific and thus may not be representative of the future.

\section{EXAMPLES OF LITERATURE ON INTERNATIONAL DIVERSIFICATION}


The article by Grubel (1968) is a commonly cited early article on the benefits of international diversification. He observes that a portfolio limited to a single country's securities have individual security returns that will tend to move in a highly synchronized manner, making diversification difficult. For this reason, we can intuitively consider that the individual securities of an international portfolio will be more likely to move somewhat independently of each other than those in a domestic portfolio. Levy and Sarnat (1970), among others, present early support for the hypothesis that international diversification can bring about significant risk reductions greater than those achievable by sole domestic diversification. Solnik (1974) demonstrated the risk reduction benefits of including European stocks with U. S. stocks. However, contradictory evidence has been presented by Ho, Milevsky, and Robinson (1999) and Hanna, McCormack and Perdue (1999) who report few benefits, if any, arising from international diversification.

Regarding investments in emerging foreign markets, Errunza (1971) presented evidence that optimal international diversification must include securities from developing countries. Errunza and Losq (1987) further contend that investors should not avoid politically unstable regions where returns prospects may outweigh the risks. Sudweeks (1989), among others, argues that many of the perceived or actual problems of indirectly investing in emerging markets are rapidly diminishing. Cosset and Suret (1995) examine the benefits of portfolio investment in the stock markets of politically risky countries by evaluating the effects of political risk constraints on the performance of a portfolio of international stocks. Their findings suggest that diversification among such markets improves the risk/return characteristics of optimal portfolios. Conover, et al. (2002) examine 24 years of returns data and conclude that a diversified portfolio of emerging market equities is a valuable addition to U.S. portfolios. The emerging market equities considered by Conover, et al. included markets from around the world, and the benefit of emerging market equities occurred primarily when U.S. monetary policy was restrictive.

With regard to Latin America, Barry and Rodriguez (1999) report their analysis of the returns, risk, and diversification characteristics of the Latin American markets between 1975 and 1998 . With the exception of Argentina and Chile, Latin American markets underperformed their U.S. counterpart because of greater risk. The correlations of returns between these markets and the U.S., however, are reported to be relatively low, which suggests that gains from diversification in this region are possible.

Overall the literature in finance reports clear return/risk benefits associated with international diversification and also concludes that emerging markets offer significant returns and diversification opportunities. As with smallcompany stocks in the U.S., investors should evaluate the returns potential of emerging markets in the context of the additional risks they bring to a portfolio in order to determine whether an optimized portfolio should include such stocks.

\section{MEXICO: A VIABLE OPTION FOR U.S. PORTFOLIO DIVERSIFICATION}

In the past couple of decades Mexico has undergone a transition that has made its economy more closely related to that of its NAFTA partners than to the economies of its Latin American cultural peers. Statistics published by Banco de Mexico (2005) report the expansion of Mexican economic activity and GDP in the 1990s. The expansion of the Mexican economy has occurred partly as a result of increased integration with the North American market and efficient use of monetary policy. We suggest that these events have brought about a qualitative change to the country that is of interest to equity investors. Mexico has changed from a Latin American emerging market to an emerging economy that more closely follows the U.S. industrial production cycle. Both U.S. and Mexican economies are tightly woven in a tapestry of international trade, direct investment, and joint production processes. Also, as a result of economic policy reform Mexico has experienced significantly less volatility of inflation and industrial production in the last decade.

The correlations between the Standard \& Poor's 500 Index (S\&P 500) and the MSCI Mexico Index provide interesting evidence of the integration of the Mexican economy with the U.S. economy. The simple correlation between monthly total returns to the S\&P 500 and the MSCI Mexico Index for January 1988 through December 2004 was 0.49 . In the first 68 months of that sample the correlation was lowest at 0.36 . In the second 68 months the correlation was 0.50 , and in the last 68 months the correlation was 0.72 . Thus the increasing correlations between the 
stock market returns of the two countries are supportive of the suggestion that NAFTA has facilitated a stronger relationship between the economies of Mexico and the U.S.

Table 1 below presents statistics on average monthly returns and standard deviations of returns of diversified common stock investments in Mexico, the U.S., and Canada. The data reported in Table 1 suggest that the MSCI Mexican stock market in 1988 through 2004-with an average monthly return of 2.273 percent - was an attractive investment relative to the more developed NAFTA partners. As expected of an emerging market, the sample standard deviations of monthly returns to the Mexican stock market have been comparatively high and variable. However, in recent years the risk of Mexican stock investments has been more in line with the U.S. and Canadian markets. The low correlation with the S\&P 500 combined with the higher returns and declining risk suggest that the Mexican stock market offers beneficial diversification opportunities for U.S. investors.

Table 1

Sample Average Monthly Total Returns and Standard Deviations of Returns

\begin{tabular}{|c|c|c|c|c|}
\hline \multirow[b]{3}{*}{ Average monthly returns: } & \multirow{3}{*}{$\begin{array}{c}\text { Jan- } 88 \\
\text { to Dec-04 } \\
\end{array}$} & \multicolumn{3}{|c|}{ 68-Month Sub-Samples: } \\
\hline & & Jan-88 & Sep-93 & May-99 \\
\hline & & to Aug-93 & to Apr-99 & to Dec-04 \\
\hline S\&P 500 & $1.066 \%$ & $1.275 \%$ & $1.825 \%$ & $0.100 \%$ \\
\hline MSCI Mexican stock market & $2.273 \%$ & $4.636 \%$ & $0.890 \%$ & $1.294 \%$ \\
\hline MSCI Canadian stock market & $0.949 \%$ & $0.598 \%$ & $1.172 \%$ & $1.077 \%$ \\
\hline \multicolumn{5}{|l|}{ Standard deviations of returns: } \\
\hline S\&P 500 & $4.132 \%$ & $3.677 \%$ & $3.857 \%$ & $4.666 \%$ \\
\hline MSCI Mexican stock market & $9.763 \%$ & $9.836 \%$ & $11.436 \%$ & $7.259 \%$ \\
\hline MSCI Canadian stock market & $5.021 \%$ & $3.714 \%$ & $5.339 \%$ & $5.822 \%$ \\
\hline 30-day US Treasury bill returns & $0.246 \%$ & $0.479 \%$ & $0.393 \%$ & $0.241 \%$ \\
\hline
\end{tabular}

Notes: USA monthly returns are total returns to the $\mathrm{S} \& \mathrm{P} 500$ as reported by Ibbotson Associates (2005). Mexican and Canadian equity returns are calculated the MSCI indexes respectively. The risk-free rate is the average monthly return to 30-day U. S. Treasury bills for the sample period. Monthly U. S.Treasury bill returns are those reported by Ibbotson Associates (2005)

\section{CANADA: TOO CLOSE TO THE U.S.?}

The implementation of NAFTA in 1994 has allowed Canada to continue to enjoy considerable export-driven economic prosperity. According to Statistics Canada (2005), Canada sends 83 percent of its exports to the US. This, combined with 70 percent of total imports from the U.S., has created an increase of merchandise trade with the U.S. of over 120 percent. These exports account for more than 20 percent of Canada's GDP, which is the highest among all other G7 countries. Although some of this trade growth may be attributed to NAFTA, some of the trade growth and economic integration between the U.S. and Canada must be attributed to the 1988 Canada-U.S. Free Trade Agreement.

The trade liberalization that came about due to the 1988 agreement and the subsequent NAFTA opened the Canadian economy to the rest of North America. As a result, Canada's trade exposure (imports plus exports, as a percentage of GDP) doubled between 1970 and 2000 and peaked at 85 percent of GDP in 2000. In the last several 
decades, Canada's GDP has grown to over $\mathrm{C} \$ 1.25$ trillion. Similar to other advanced economies, many forces contributed to the advancement of the Canadian economy including globalization, technological change, economic regulations and trade policies, such as NAFTA, and the growing importance of services in the economy.

Economic statistics on the link between the Canadian economy and the U.S. economy suggest that there is little diversification benefit to be gained by including Canadian stocks in U.S. portfolios. Geography and earlier trade agreements with the U.S. explain why the impact of NAFTA on the Canadian economy was somewhat less than on Mexico. The correlations of monthly returns to the S\&P 500 and the MSCI Canada Index are 0.63 for the 68 months from January 1998 to August 1993, 0.81 for the 68 months of September 1993 to April 1999, and 0.80 for the remaining 68 months of our sample ending December 2004. The correlation between the monthly returns to the two markets for the entire 204 months of our sample was 0.75 .

Clearly the U.S. and Canadian stock markets are closely related, as one would expect. As shown in Table 1 the sample average monthly returns to Canadian stocks was somewhat lower than that of the S\&P 500, and the sample standard deviation of returns was slightly higher. Thus the longer-term convergence of the Canadian economy with the U.S. economy and the evidence on stock market returns suggest that Canada is not a good international diversification alternative for U.S. portfolios. Additional evidence is presented below that supports this contention.

\section{METHODOLOGY}

The objective of our analysis was to calculate optimal allocations of U.S., Mexican and Canadian stocks in equity portfolios. The returns data are monthly returns to the MSCI (2005) country stock indexes for Mexico and Canada and monthly returns to the S\&P 500. All three indexes are available to investors in the form of exchange traded funds (ETF) offered on the American Stack Exchange as iShares MSCI-Mexico (Ticker: EWW), iShares MSCI-Canada (Ticker: EWC) and SPDRS (Ticker: SPY).

Because the MSCI Mexico stock index data begin with December 1987, our analysis is necessarily limited to monthly returns for January 1988 through December 2004, a total of 204 months. The Mexican and Canadian stock returns are total returns in U.S. dollars. The S\&P 500 returns are total returns as reported by Ibbotson Associates (2005). Sample monthly total returns, standard deviations of returns, and correlations between the Mexican, Canadian and the S\&P 500 are reported above. The 204-month correlation between Mexican stock returns and Canadian stock returns was 0.45 . The Mexican/Canadian stock market correlations in the three 68-month sub-samples were 0.18 , 0.54 , and 0.67 respectively. These correlations suggest possible support for the inclusion of Canadian stocks in an optimized three-security stock portfolio, but they also show the increasing integration of North American markets generally.

The Sharpe ratio that is maximized in optimally weighted portfolio is

Sharpe ratio $=\left(\mathrm{TR}_{\mathrm{p}}-\mathrm{RF}\right) / \mathrm{SD}_{\mathrm{p}}$

where:

$\mathrm{TR}_{\mathrm{p}}=$ average monthly return to the portfolio for the sample months,

$\mathrm{RF}=$ average monthly return to 30-day U.S. Treasury bills for the sample months, and

$\mathrm{SD}_{\mathrm{p}}=$ standard deviation of monthly returns to the portfolio for the sample months.

The portfolio asset allocation weights for the S\&P 500, Mexican stocks, and Canadian stocks are optimal when the Sharpe ratio is maximized. Other risk measurements have been proposed in similar research. Keppler and Lechner (1997) examined a wide range of measures of portfolio risk in addition to standard deviation including the Keppler ratio which replaces standard deviation of returns in the Sharpe ratio their estimate expectation of monthly loss. However, because the Sharpe ratio is widely-recognized and relied on in portfolio management, we focus our portfolio optimization analyses on maximizing the Sharpe ratio as presented in Equation (1). Also, since the securities 
that are themselves diversified portfolios of those countries' stocks are combined to form perhaps more efficient portfolios, standard deviation is a more appropriate measure of portfolio risk than country betas.

Using Excel's Solver algorithm, we constrained the portfolio weights to positive values; thus excluding short positions, and then calculated the set of portfolio weights of the S\&P 500, the MSCI Mexico Index, and the MSCI Canadian stock index that maximized the Sharpe ratio for the sample period. The first optimization calculation included all 204 monthly returns in our sample. Subsequently, three non-overlapping samples of 68 months were created and optimal portfolio weights of the three stock indexes were derived for those periods.

\section{FINDINGS}

The optimal portfolio weights, returns to the indexes, standard deviation of returns, optimized portfolio returns and standard deviations, and risk-free rates are reported in Table 2 below. The results summarized in Table 2 suggest that the long-run optimal weights for stocks in North American equity portfolios are 67 percent invested in the S\&P 500, 33 percent in the Mexican stock index, and nothing invested in Canadian stocks. Those weights are the result of comparatively high returns to the S\&P 500 relative to risk in the pre-2000 years of the sample and the generally high returns of Mexican stocks with the exception of 1994 and 1995.

Canadian stock returns were steady through the sample period, but the standard deviations of Canadian stock returns excluded Canadian stocks from the optimal portfolios in all but the most recent sub-sample. In the first 68month sample, Mexican stocks dominate because of the very high average returns of 4.64 percent per month. In the second 68-month period, the very high returns to U.S. stocks relative to risk completely dominate the optimality analysis, excluding both Mexican and Canadian stocks. The September 1993 to April 1999 sample also includes the Peso devaluation of 1994 that resulted in substantial losses in 1994 and 1995. In the most recent 68-month sample, the S\&P 500 is excluded by the low average returns to U.S. stock markets in the 2000 to 2004 period. There findings are consistent with Bekaert and Urias (1999) who found that the returns advantages of emerging markets vary among sub-samples in the returns data. As emerging markets converge with developed markets, the correlations increase and expected returns in emerging markets are bid down by investors.

The portfolio optimization results in Table 2 suggest that U.S. investors should consider significant portfolio allocations to a widely diversified portfolio of Mexican stocks. Such a conclusion assumes that the risk, returns, and correlations relied upon in the analysis above are stable and are available to investors in the form of mutual funds, closed-end funds or ADRs. The increasing correlations among the three markets and the sample specific results of the analysis are cautionary aspects of our analysis. If the returns in 208-month sample are considered to be expected future returns, Mexican stocks would represent about a 25 percent to 35 percent allocation in a North American equities portfolio. However, recent increases in the correlation between the U.S. and Mexican stock markets may suggest a smaller allocation to Mexican stocks.

What is the payoff to the investor? In order to test the advantage of the optimal portfolio consisting of 67 percent S\&P 500 and 33 percent Mexican stocks, portfolio survival rates were calculated for S\&P 500 portfolios, Mexican stock portfolios, Canadian Stock portfolios, and for the optimal portfolio net of inflation-adjusted cash withdrawals. The survival rates are the percentages of simulated portfolios that survived 15, 20, 25, and 30-year payout periods with continuously positive values net of 3 percent to 10 percent initial annual withdrawals from the year-end portfolio values. The returns and standard deviations of returns to the portfolios were restated in annual values and were the inputs to standard Monte Carlo simulations. 
Table 2

Optimized Portoflios of North American Equities Derived From 1988 - 2004

Using Monthly Total Returns

\begin{tabular}{llll}
\multicolumn{3}{c}{ Stock Markets } & \\
\hline S\&P 500 & Mexico & Canada & Portfolio
\end{tabular}

A. 204 Months, January 1988 - December 2004:

Optimal weights

Average monthly return

Standard deviation of returns

Risk-free rate/month

Sharpe ratio

B. 68 Months, January 1988 - August 1993:

Optimal weights

Average monthly return

Standard deviation of returns

Risk-free rate/month

Sharpe ratio

C. 68 Months, September 1993 - April 1999:

Optimal weights

Average monthly return

Standard deviation of returns

Risk-free rate/month

Sharpe ratio

D. 68 Months, May 1999 - December 2004:

$\begin{array}{llll}0.674 & 0.326 & 0.000 & 1.000 \\ 1.07 \% & 2.27 \% & 0.95 \% & 1.46 \% \\ 4.13 \% & 9.76 \% & 5.02 \% & 5.14 \% \\ & & & 0.25 \% \\ & & & 0.236\end{array}$

$\begin{array}{llll}0.326 & 0.674 & 0.000 & 1.000 \\ 1.27 \% & 4.64 \% & 0.60 \% & 3.54 \% \\ 3.68 \% & 9.84 \% & 3.71 \% & 7.10 \% \\ & & & 0.48 \% \\ & & & 0.431\end{array}$

$\begin{array}{llll}1.000 & 0.000 & 0.000 & 1.000\end{array}$

$1.82 \% \quad 0.89 \% \quad 1.17 \% \quad 1.82 \%$

$3.86 \% \quad 11.44 \% \quad 5.34 \% \quad 3.86 \%$

$0.39 \%$

0.371

$\begin{array}{llll}0.000 & 0.458 & 0.542 & 1.000 \\ 0.10 \% & 1.29 \% & 1.08 \% & 1.18 \% \\ 4.67 \% & 7.26 \% & 5.82 \% & 5.87 \% \\ & & & 0.24 \% \\ & & & 0.159\end{array}$

Notes: USA monthly returns are total returns to the S\&P 500 as reported by Ibbotson Associates (2005). Mexican and Canadian equity returns are calculated the MSCI indexes respectively. The risk-free rate is the average monthly return to 30-day U. S. Treasury bills for the sample period. Monthly U. S.Treasury bill returns are those reported by Ibbotson Associates (2005) 
In the simulations an annual return is drawn randomly from the distributions of returns to the relevant indices, assuming returns are log-normally distributed. The 204-month sample average annualized returns and annualized standard deviations of returns for the three indexes were as follows:

\begin{tabular}{|l|c|c|}
\hline & Returns & Standard Deviations \\
\hline S\&P 500 Index & $12.80 \%$ & $14.32 \%$ \\
\hline MSCI Mexican Index & $27.28 \%$ & $33.82 \%$ \\
\hline MSCI Canadian Index & $11.39 \%$ & $17.39 \%$ \\
\hline 0.33 Mexico/0.67 S\&P 500 & $17.51 \%$ & $17.82 \%$ \\
\hline
\end{tabular}

The year-end value of a portfolio in the simulation is

$\mathrm{V}_{\mathrm{t}}=\mathrm{V}_{\mathrm{t}-1}\left(1+\mathrm{R}_{\mathrm{t}}\right)-\mathrm{w}\left(\mathrm{V}_{0}\right)(1.03)^{\mathrm{t}-1}$

where:

$\mathrm{V}_{\mathrm{t}}=$ the value of the portfolio at the end of a year,

$\mathrm{R}_{\mathrm{t}}=$ the randomly drawn total return to the portfolio for that year,

$\mathrm{w}=$ the assumed withdrawal rate, and

$\mathrm{t}=$ years iterating from 1 to the last year in the payout period.

Each year's withdrawal amount after the first year is increased by 3 percent over the previous year's withdrawal amount in order to add reasonable inflation adjustments to the annual withdrawals. If a simulated portfolio completed an $\mathrm{n}$-year payout period with $\mathrm{V}_{\mathrm{n}}>0$, it was recorded as a survivor. The percentages that are reported in Table 3 are the percentages of portfolios that survived the payout periods with final values that were greater than zero. The annual returns were assumed to be serially independent in the Monte Carlo simulations. Thus, there were no adjustments made for mean reversion or serial correlation, if any exists, in the returns data.

Table 3 below presents the survival rates calculated by Monte Carlo simulation. Each survival rate in Table 3 is the percentage of 5,000 simulated portfolios in 15,20,25, and 30-year payout periods that survived the payout periods net of annual inflation-adjusted withdrawals that began at 3 percent to 10 percent of the initial portfolio values. For example, 82 percent of the 5,000 simulated S\&P 500-only portfolios through 20 -year payout periods survived the 20 years with positive values net of 7 percent initial withdrawals plus 3 percent annual inflation adjustments; 93 percent of Mexican stock portfolios survived 20-year payout periods net of 7 percent inflationadjusted withdrawals; 61percent of Canadian stock portfolios survived 20-year payout periods net of 7 percent inflation-adjusted withdrawals; and 96percent of the S\&P 500/Mexican stock portfolio survived 20-year payout periods net of 7 percent inflation-adjusted withdrawals. Higher survival rates suggest higher potential payoffs to an investor from the investments.

The survival rates in Table 3 demonstrate the benefit of the comparatively high returns to the Mexican stock index. Of course, returns to the Mexican stock index may be upwardly biased by survivorship of the companies in the index. That is, the returns may not fully reflect the impact of the failures of individual companies that were removed from the index. Nevertheless, the survival rate analysis suggests that U.S. investors give serious attention to diversified investments in the Mexican stock market.

\section{CONCLUSIONS}

This paper addresses the extent to which the performance of a diversified portfolio of U.S. stocks can be improved by the inclusion of Canadian and Mexican equities. The main result reflects the findings of previous studies, that a diversified portfolio of Mexican stocks has had the return/risk characteristics to offer significant diversification and higher returns opportunities for U.S. investors. The optimization analysis reported in Table 2 
suggests an optimal North American equities portfolio of about 67 percent U.S. stocks and 33 percent Mexican stocks. This finding assumes that the observed 17-year relationship between monthly returns to the MSCI Mexico Index relative to the S\&P 500 is stable in the long-run and achievable through investment vehicles such as mutual funds, closed-end funds, and ADRs. The results of the Monte Carlo analysis reported in Table 3 demonstrate the practical advantage of a U.S./Mexico equities portfolio in comparison to a U.S. equity portfolio. Higher portfolio withdrawal rates appear more likely to be sustainable with a Mexico/U.S. portfolio than with a U.S. equity portfolio. Our analysis suggests that Canadian stocks appear not to offer much diversification or return advantage to U.S. investors.

Table 3

Payout Period Survival Rates of Portfolios of North American Stocks

\begin{tabular}{|c|c|c|c|c|c|c|c|c|}
\hline & \multicolumn{8}{|c|}{ Initial Annual Withdrawal Rate } \\
\hline & $3 \%$ & $4 \%$ & $5 \%$ & $6 \%$ & $7 \%$ & $8 \%$ & $9 \%$ & $10 \%$ \\
\hline \multicolumn{9}{|l|}{ 100\% S\&P 500: } \\
\hline 15 years & $100 \%$ & $100 \%$ & $100 \%$ & $99 \%$ & $95 \%$ & $85 \%$ & $71 \%$ & $53 \%$ \\
\hline 20 years & $100 \%$ & $100 \%$ & $99 \%$ & $94 \%$ & $82 \%$ & $67 \%$ & $49 \%$ & $30 \%$ \\
\hline 25 years & $100 \%$ & $99 \%$ & $96 \%$ & $87 \%$ & $73 \%$ & $54 \%$ & $35 \%$ & $20 \%$ \\
\hline 30 years & $100 \%$ & $99 \%$ & $94 \%$ & $81 \%$ & $64 \%$ & $45 \%$ & $28 \%$ & $15 \%$ \\
\hline \multicolumn{9}{|l|}{ 100\% Mexico: } \\
\hline 15 years & $100 \%$ & $100 \%$ & $99 \%$ & $98 \%$ & $97 \%$ & $94 \%$ & $91 \%$ & $85 \%$ \\
\hline 20 years & $100 \%$ & $100 \%$ & $99 \%$ & $97 \%$ & $95 \%$ & $92 \%$ & $86 \%$ & $81 \%$ \\
\hline 25 years & $100 \%$ & $99 \%$ & $98 \%$ & $97 \%$ & $93 \%$ & $90 \%$ & $85 \%$ & $79 \%$ \\
\hline 30 years & $100 \%$ & $99 \%$ & $98 \%$ & $95 \%$ & $93 \%$ & $89 \%$ & $84 \%$ & $78 \%$ \\
\hline \multicolumn{9}{|l|}{ 100\% Canada: } \\
\hline 15 years & $100 \%$ & $99 \%$ & $97 \%$ & $91 \%$ & $81 \%$ & $65 \%$ & $51 \%$ & $35 \%$ \\
\hline 20 years & $99 \%$ & $97 \%$ & $89 \%$ & $77 \%$ & $61 \%$ & $44 \%$ & $30 \%$ & $18 \%$ \\
\hline 25 years & $98 \%$ & $93 \%$ & $81 \%$ & $65 \%$ & $47 \%$ & $32 \%$ & $20 \%$ & $10 \%$ \\
\hline 30 years & $97 \%$ & $88 \%$ & $73 \%$ & $55 \%$ & $37 \%$ & $25 \%$ & $14 \%$ & $8 \%$ \\
\hline \multicolumn{9}{|c|}{ 67\% S\&P 500/33\% Mexico: } \\
\hline 15 years & $100 \%$ & $100 \%$ & $100 \%$ & $100 \%$ & $98 \%$ & $95 \%$ & $90 \%$ & $81 \%$ \\
\hline 20 years & $100 \%$ & $100 \%$ & $99 \%$ & $98 \%$ & $96 \%$ & $89 \%$ & $81 \%$ & $69 \%$ \\
\hline 25 years & $100 \%$ & $100 \%$ & $99 \%$ & $97 \%$ & $93 \%$ & $86 \%$ & $75 \%$ & $60 \%$ \\
\hline 30 years & $100 \%$ & $100 \%$ & $99 \%$ & $97 \%$ & $91 \%$ & $82 \%$ & $69 \%$ & $56 \%$ \\
\hline
\end{tabular}

Notes: Monte Carlo analysis was used to calculate the percentage of portfolios that survived the payout periods with positive values. The returns data were January 1988 through December 2004. Mexican and Canadian market returns are calculated from the respective MSCI indexes. A total of 5000 Monte Carlo iterations were calculated to derive each of the survival rates.

Our research findings encourage U.S. investors to give serious consideration to investment in a diversified portfolio of Mexican stocks or similar emerging market stocks in optimizing the equity allocations of their portfolios. Also, the portfolio survival rate analysis in Table 3 suggests that investors who start late in the accumulation phase of their lives may find that the higher return and riskier investments in emerging markets, such as Mexico, can make up for lost time and lack of saving in the lower-risk, lower return developed markets. Similarly, investors who require 
higher withdrawal rates from their portfolios may find those higher withdrawal rates to be more sustainable for portfolios with Mexican or similar emerging markets stocks. Risk, of course, is a two-edged sword, and investors who consider high-risk strategies for accumulation or withdrawals should be prepared for the downside as well as the upside of market volatility.

Because of the rising correlation between Mexican and U.S. stock returns in the sub-sample periods, the findings and conclusions are tentative. If future returns to Mexican stocks relative to S\&P 500 returns are similar to those in the 17-year sample, U.S. investors would be well advised to diversify their equity holdings by acquiring shares of mutual funds or ADRs of Mexican stock. If the Mexican economy and stock market become increasing integrated with the U.S. economy and stock market, the diversification advantages demonstrated in the full 208-month sample will diminish and the optimal allocation of funds to Mexican stocks in U.S. equities portfolios is likely to be lower than the 33 percent reported in Table 2. Except when the U.S. stock market experiences unusual declines, holding Canadian stocks does not appear to provide diversification benefits for U.S. investors.

\section{REFERENCES}

1. Banco de México (2005) at http://www.banxico.org.mx

2. Barry, Chistopher and Maurico Rodriguez (1998), Investing in Latin American Equity Markets, 1975-1998, Emerging Markets Quarterly, Fall, Vol. 2, No. 3, 5-18.

3. Bekaert, Geert and Michael S. Urias (1999), Is There a Free Lunch in Emerging Market Equities? Journal of Portfolio Management, 25, 3, 83-95.

4. Conover, C. Mitchell, Gerald R. Jensen, and Robert R. Johnson (2002), Emerging Markets: When Are They Worth It? Financial Analysts Journal, March/April, Vol. 58, No. 2.

5. Cosset, Jean-Claude and Jean-Marc Suret (1995), Political Risk and the Benefits of International Portfolio Diversification, Journal of International Business Studies, Vol. 26, No. 2, 301-18.

6. Errunza, Vihang (1977), Gains from Portfolio Diversification into Less Developed Countries' Securities, Journal of International Business Studies, Vol. 8, No. 2 (Autumn - Winter), 83-99.

7. Errunza, Vihang and Etienne Losq (1987), How Risky Are Emerging Markets?, Journal of Portfolio Management, Fall, 62-67.

8. Grubel, Herbert (1968), Internationally Diversified Portfolios: Welfare Gains and Capital Flows, American Economic Review, December 1968; reprinted in International Investment, Penguin 1972, J. Dunning, editor

9. Hanna, M. J. P. McCormack, and G. Perdue (1999), A Nineties Perspective on International Diversification, Financial Services Review, 8, 37-45.

10. Ho, K. M. A. Milevsky, and C. Robinson (1999), International Equity Diversification and Shortfall Risk, Financial Services Review, 8, 11-25.

11. Ibbotson Associates. 2005. Stocks, Bonds, Bills, and Inflation 2005 Yearbook. Chicago, IL: Ibbotson Associates.

12. Keppler, Michael and Martin Lechner (1997), Emerging Markets: Research, Strategies and Benchmarks, Chicago: Irwin Professional Publishing, 1997.

13. Levy, H. and M. Sarnat (1970), International Diversification of Investment Portfolios, American Economic Review, 60, 668-75.

14. MSCI 2005, Morgan Stanley Capital Inc., Mexican and Canadian Equity Indexes at http://www.msci.com/equity/index2.html, accessed August 3, 2005.

15. Solnik, Bruno (1974), Why Not Diversify Internationally Rather Than Domestically? Financial Analysts' Journal, July/August, 48-54. Reprinted in the 1995 Financial Analysts' Journal, September/October, 17-33.

16. Statistics Canada (2005) at http://www.statcan.ca

17. Sudweeks, Bryan (1989), Equity Market Development in Developing Countries, New York: Praeger Publishers. 


\section{NOTES}

